\title{
Correction: Primary malignant non-Hodgkin's lymphoma of the breast: a study of seven cases and literature review
}

Bourhafour Mouna ${ }^{1 *}$, Boutayeb Saber ${ }^{1}$, El Harroudi Tijani ${ }^{2}$, M'rabti Hind $^{1}$, Taleb Amina ${ }^{1}$ and Errihani Hassan ${ }^{1}$

\section{Correction}

After publication of this work [1], we noted that we had inadvertently included Bodmer Alexandre, CastiglioneGertsch Monica and Pierre Yves Dietrich as authors of the study. The list of authors has now been corrected and the Authors' contributions and Competing interests section modified accordingly.

\section{Competing interests}

The authors declare that they have no competing interests.

\section{Authors' contributions}

MB drafted the manuscript. EH T participated in the design of the study. MB reviewed the final manuscript and revised it critically for important

intellectual content. All authors read and approved the final manuscript.

\section{Author details}

${ }^{1}$ Department of Medical Oncology, National Institute of Oncology, Rabat 10000, Morocco. ${ }^{2}$ Faculty of Medicine, Oujda, Morocco, Department of Surgery, National Institute of Oncology, Rabat 10000, Morocco.

Received: 9 October 2012 Accepted: 9 October 2012

Published: 11 October 2012

\section{Reference}

1. Primary malignant non-Hodgkin's lymphoma of the breast: a study of seven cases and literature review. World J Surg Oncol 2012, 10:151. 10.1186/1477-7819-10-151.

\footnotetext{
* Correspondence: bourhafourmouna@yahoo.fr

${ }^{1}$ Department of Medical Oncology, National Institute of Oncology, Rabat 10000, Morocco

Full list of author information is available at the end of the article
}

Submit your next manuscript to BioMed Central and take full advantage of:

- Convenient online submission

- Thorough peer review

- No space constraints or color figure charges

- Immediate publication on acceptance

- Inclusion in PubMed, CAS, Scopus and Google Scholar

- Research which is freely available for redistribution

Submit your manuscript at www.biomedcentral.com/submit (c) 2012 Mouna et al.; licensee BioMed Central Ltd. This is an Open Access article distributed under the terms of the Creative Commons Attribution License (http://creativecommons.org/licenses/by/2.0), which permits unrestricted use, distribution, and reproduction in any medium, provided the original work is properly cited. 